\title{
Biomass Combined Heat and Power Generation for Anticosti Island: A Case Study
}

\author{
Theleli Abbas*, Mohamad Issa, Adrian Ilinca, Ali El-Ali \\ Wind Energy Research Laboratory, University of Quebec, Rimouski, Canada \\ Email: ^Thileli.ab@gmail.com, missa@imq.qc.ca, A.elali@mps.com.lb
}

How to cite this paper: Abbas, T., Issa, M., Ilinca, A. and El-Ali, A. (2020) Biomass Combined Heat and Power Generation for Anticosti Island: A Case Study. Journal of Power and Energy Engineering, 8, 64-87. https://doi.org/10.4236/jpee.2020.83005

Received: December 24, 2019

Accepted: March 28, 2020

Published: March 31, 2020

Copyright $\odot 2020$ by author(s) and Scientific Research Publishing Inc. This work is licensed under the Creative Commons Attribution International License (CC BY 4.0).

http://creativecommons.org/licenses/by/4.0/

(c) (i) Open Access

\begin{abstract}
Combined heat and power ( $\mathrm{CHP}$ ) plants (co-generation plants) using biomass as fuel, can be an interesting alternative to the predominant electrical heating in Canada. The biomass-fueled boiler provides heat for the steam cycle which in turn generates electricity from the generator connected to the steam turbine. In addition, heat from the process is supplied to a district heating system. The heat can be extracted from the system in a number of ways, by using a back-pressure steam turbine, an extraction steam turbine or by extracting heat directly from the boiler. The objective of the paper is the design, modeling and simulation of such CHP plant. The plant should be sized for providing electricity and heat for the Anticosti Island community in Quebec.
\end{abstract}

\section{Keywords}

CHP (Combined Heat and Power), Anticosti Island, Cogeneration, Heating Network, RET (Renewable Energy Technologies), Feasibility

\section{Introduction}

More than 95\% of Quebec electricity is produced in hydro-power plants which put this province in the top North American province when it comes to the share of renewable energy in final consumption. However, most of the electricity comes from large hydro power plants and ends as the heat energy for residential heating due to the undeveloped district heating systems. As residential sector is also responsible for the greenhouse gasses emissions, we come to conclusion that energy system in Canada still needs to be developed. In addition, there are more than 34,000 people who are not connected to the government grid in Quebec such as the case of Anticosti Island. One of the possible solutions is using combined heat and power (CHP) technology which is raising efficiency of the con- 
ventional electricity production by using the process waste heat. Waste heat can be used in district heating systems, which can decrease the need for the electricity in heating applications. If carbon neutral fuel, such as biomass is used to power CHP power plant, the problem with greenhouse gas emission could be solved.

Combined heat and power production or cogeneration are the generation of multiple forms of useful energy (usually electric and heat) in a single integrated system. Type of CHP system is usually identified by the type of equipment that drives the overall system (primary mover). It can be internal combustion engine, combustion or gas turbine, steam turbine, micro turbines or the fuel cell [1]. These components are using heat from the combustion of fuel to generate mechanical power which is usually used to generate electricity, but it can be also used to drive rotating equipment such as compressors, pumps and fans. Thermal energy from the process can be used in direct process applications or to produce steam, hot water, hot air, or chilled water for the adsorption cooling process [2].

The aim of this work is to investigate the possibilities for using biomass powered CHPs in Anticosti island in Quebec. For that purpose, a case study is going to be done and a suitable steam cycle CHP plant will be designed to satisfy the needs of Port-Menier power plant at Anticosti island. For the design and simulation needs, RETScreen software package is going to be used. Based on the CHP's input heating value, several possible biomass feedstocks will be considered. Availability, price, lower heating value and sustrainability will be considered when selecting, but as well in the discussion and comparative analysis. The rest of the paper is organized as follows: Section 2 presents a basic overview of CHP technologies including advantages and disadvantages of each; section 3 presents an overview of biomass and the socio-economic benefits with local bioenergy production while section 4 to 6, presents the profile of the off-grid Anticosti island in Quebec and we discuss the results obtained. Finally, in section 5, we provide a preliminary conclusion with a perspective for the future work.

\section{Combined Heat Power Technologies-An Overview}

In cogeneration, or combined heat and power technologies, fuel is combusted to provide both electricity and useful heat in the form of steam. By utilizing the energy from the biomass for both electricity generation and heat, the efficiency of energy recovery is significantly higher than systems that recover heat or electricity only. Although natural gas and coal are currently the main fuels used in CHP plants, a wide variety of fuels can be used, including biomass. Biomass can either by burnt directly, or alternatively converted to biogas which is used in the $\mathrm{CHP}$ engine. Cogeneration is already used commercially around the world in a variety of applications for baseload electricity and heat supply. In 2010, more than 10 percent of the world's electricity was generated in CHP plants [3]. Its successful application relies on a baseload demand for the heat close to the power station, while the electricity can either be used on-site (which is the more effi- 
cient option as it avoids transmission losses) or fed into the grid.

The costs of CHP systems are dependent on the size of the installation, location, etc. CHP systems are more expensive than biomass combustion systems, with the range of capital costs (in $2010 \mathrm{USD} / \mathrm{kW}$ ) being seen in various studies ranging from 3550 to $6820 \mathrm{USD} / \mathrm{kW}$ installed capacity for stoker boiler systems and 5570 to $6545 \mathrm{USD} / \mathrm{kW}$ in-stalled capacity for bubbling and circulating fluidized boilers. The levelized cost of electricity ranged between 0.07 and 0.29 $\mathrm{USD} / \mathrm{kWh}$, with little difference between the two technologies. This includes the credit associated with heat generation [4].

CHP plants are similar to those used in combustion and include feed preparation (size reduction and possibly drying), combustion in a boiler, steam generation and an electrical turbine to generate electricity. In CHP plants the steam from electricity generation is piped off for further use. Figure 1 presents a schematic of the CHP process.

A wide range of sizes of CHP plants have been built around the world, ranging from small-scale plants of $1 \mathrm{~kW}$ to large power stations of a few hundred MW. The largest biomass power station in the world is the Alholmens Kraft Power Station in Finland, which delivers 240 MW of electrical output, 100 MW of process heat and $60 \mathrm{MW}$ of district heating (Alholmens Kraft Power Station 2012) [5]. CHP power stations operating on fossil fuels can be larger than those using biomass, with plants of over $1000 \mathrm{MW}$ having been built.

For plants larger than $1 \mathrm{MW}$, equipment is typically custom built for the individual application. Modular units for smaller-scale applications (up to $5 \mathrm{MW}$ ) are, however, available, and are often used in areas with no or limited grid access. CHP plants are usually sized to meet heat demand rather than electrical

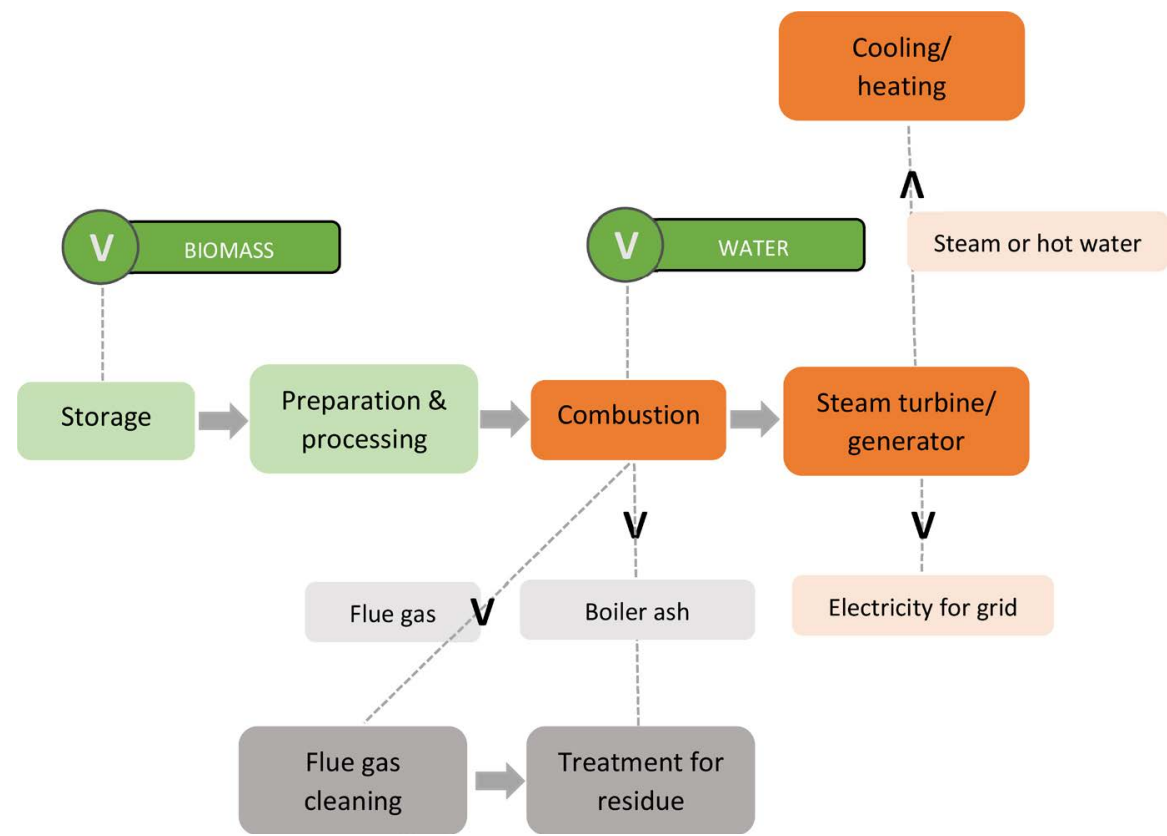

Figure 1. A block flow diagram of the process of electricity generation and heat recovery via CHP. 
demand, with any additional electricity produced being sold back to the grid [6].

Electrical efficiencies of biomass plants can be similar to combustion, although in modern plants electrical efficiency can reach 33 - 34 percent, and up to 40 percent if operated in electricity-only mode. However, with inclusion of the recovery of heat the overall energy efficiency recovery is anywhere from 75 to more than 90 percent, depending on the age and sophistication of the plant [7]. In Table 1 is given a basic overview of CHP technologies, advantages and disadvantages, including available sizes [8].

\subsection{Gas Turbine Technology}

Gas turbines are the most used technology in CHP systems, but it can also be used in power-only generation. They produce high-quality exhaust heat that can be used in CHP systems to reach overall efficiency of 70\% to $80 \%$. The most efficient technology for power-only production is gas turbine-steam turbine combined-cycle plant where efficiency can go up to $60 \%$ of the fuel LHV [9], while

Table 1. Summary of combined heat technologies.

\begin{tabular}{|c|c|c|c|}
\hline CHP System & Advantages & Disadvantages & Available sizes \\
\hline Gas Turbine & $\begin{array}{l}\text { - High reliability } \\
\text { - Low emissions } \\
\text { - High grade heat available } \\
\text { - No cooling required }\end{array}$ & $\begin{array}{l}\text { - Require high pressure gas or inhouse gas } \\
\text { compressor } \\
\text { - Poor efficiency at low loading } \\
\text { - Output falls as ambient temperature rises }\end{array}$ & \\
\hline Micro Turbine & $\begin{array}{l}\text { - Small number of moving parts } \\
\text { - Compact size and light weight } \\
\text { - Low emissions } \\
\text { - No cooling required }\end{array}$ & $\begin{array}{l}\text { - High cost } \\
\text { - Relatively low mechanical efficiency } \\
\text { - Limited to lower temperature cogeneration } \\
\text { applications }\end{array}$ & $30 \mathrm{KW}-250 \mathrm{KW}$ \\
\hline $\begin{array}{l}\text { Internal Combustion } \\
\text { Engine }\end{array}$ & $\begin{array}{l}\text { - High power efficiency with part-load } \\
\text { operational flexibility } \\
\text { - Fast start up } \\
\text { - Relatively low investment cost } \\
\text { - Can be used in island mode and have } \\
\text { good load following capability } \\
\text { - Can be overhauled on site } \\
\text { - Operate on low pressure gas }\end{array}$ & $\begin{array}{l}\text { - High maintenance costs } \\
\text { - Limited to lower temperature cogeneration } \\
\text { applications } \\
\text { - Relatively high air emissions } \\
\text { - Must be cooled even if recovered } \\
\text { heat is not used } \\
\text { - High level of low frequency noise }\end{array}$ & $\begin{array}{l}<5 \mathrm{MW} \text { in distributed } \\
\text { generation } \\
\text { High speed }(1200 \mathrm{rpm}) \leq 4 \\
\text { MW } \\
\text { Low speed }(102-517 \mathrm{rpm}) 4 \\
\text { - } 75 \mathrm{MW}\end{array}$ \\
\hline Steam turbine & $\begin{array}{l}\text { - High overall efficiency } \\
\text { - Any type of fuel can be used } \\
\text { - Ability to meet more than one site heat } \\
\text { grade requirement } \\
\text { - Long working life and high reliability } \\
\text { - Power to heat ratio can be varied }\end{array}$ & $\begin{array}{l}\text { - Slow start up } \\
\text { - Low power to heat ratio }\end{array}$ & $50 \mathrm{KW}-250 \mathrm{MW}$ \\
\hline Fuel cells & $\begin{array}{l}\text { - Low emission and low noise } \\
\text { - High efficiency over load range } \\
\text { - Modular design }\end{array}$ & $\begin{array}{l}\text { - High cost } \\
\text { - Low durability and power density } \\
\text { - Fuels requiring process }\end{array}$ & $5 \mathrm{KW}-2 \mathrm{MW}$ \\
\hline
\end{tabular}


simple-cycle gas turbines for power-only production can reach $40 \%$ of the fuel LHV.

Gas turbines are considered to be one of the cleanest ways to produce electricity. Because of their high efficiency and natural gas as primary fuel, this technology emits less carbon dioxide per generated kilowatt-hour than any other fossil technology in commercial use. This technology found wide application in oil and gas industry where gas turbine is used to drive pumps and compressors. In process industries, they are used to drive compressors or other large mechanical equipment, while many other industries use turbines to generate electricity on site. When used for this purpose, gas turbines are usually used in CHP mode where energy in exhaust gases provides the thermal energy. Gas turbine systems operate on the thermodynamic cycle called Brayton cycle. In this cycle, air is compressed in a compressor, heated in the combustion chamber and then expanded in the turbine. Part of the power produced by turbine is used for the compressor. Ideal Brayton cycle is showed in Figure 2.

A schematic of a gas turbine-based CHP system is shown in Figure 3. An air intake system supplies compressed air to the compressor. This air is directed to the combustion chamber where it mixes with the gaseous fuel in the required quantities. The hot gases from the combustion chamber expand through the turbine,

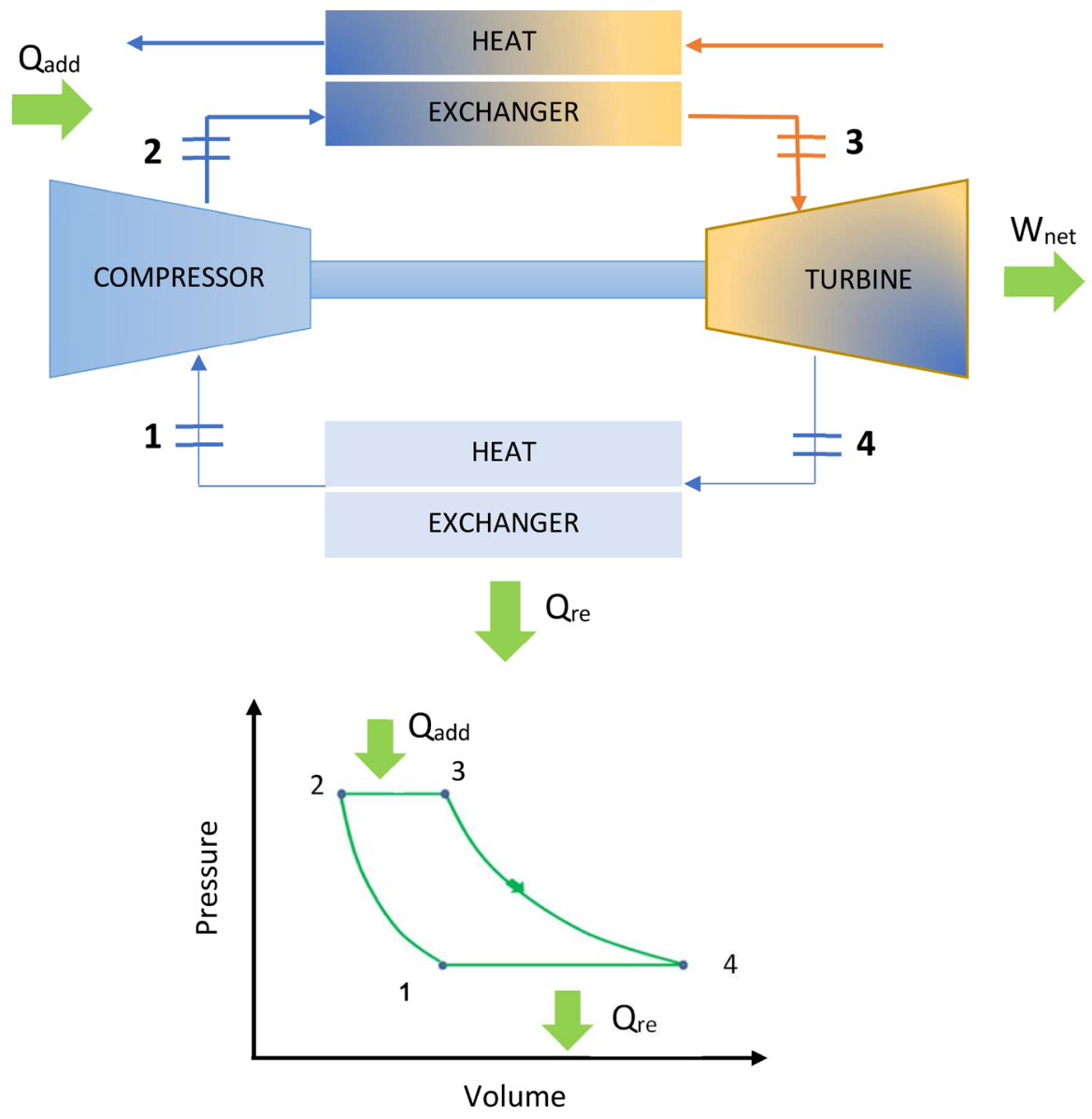

Figure 2. Ideal Brayton cycle in gas turbine [10]. 


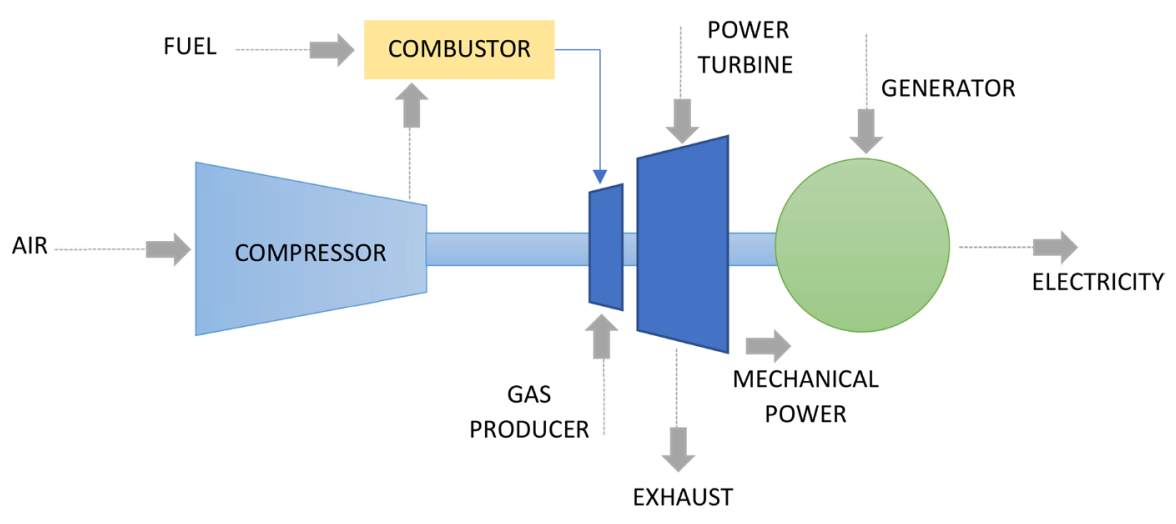

Figure 3. Gas Turbine System [11].

this operation is followed by the creation of a large amount of mechanical energy that drives the turbine rotor. The turbine shaft is connected to the compressor and generator at the same time. In the outlet flow, there is an additional combustion chamber where the temperature of the exhaust gases is increased according to the process requirements. The heat recovery boiler uses the heat from the exhaust gases to produce steam or hot water which is then used in a district heating system or other industrial processes.

\subsection{Micro Turbine Technology}

Microturbines are small electricity generators that use fuel to produce high speed rotation which is transformed to electricity in a generator [12]. They use a variety of gaseous and liquid fuels. It is a relatively new technology which started to be commercially used in 2000. Origins of this technology can be found in automotive industry in 1950's when turbochargers and turbo compressors started to be used in automobile engines.

This technology is able to provide a stable and reliable power supply with low emissions. It is ideal for distributed generation because of microturbine's flexibility in connection methods and ability to be connected parallel in order to give higher output power. Microturbines are used in financial services sector, data processing and telecommunication, hotels and restaurants, residential buildings, office buildings and in other commercial sectors. Because of the wide range and low quality of fuels that can be used in this technology, microturbines are used in resource recovering operations in oil and gas industry, coal mines and landfill operation where they use by-product gas. When used in cogeneration, waste heat from microturbines is used for the water heating, building space heating or to drive ventilation system of the building [13].

Microturbines operate on the same principle gas turbines do as they basically are small gas turbines, so they use Brayton thermodynamic cycle. Most of them have internal heat exchanger that is used to preheat compressed air, which is called recuperators. Centrifugal compressor compresses the inlet air which later goes to the recuperator. After that, preheated air is mixed with the fuel in the combustor and hot combustion gas expands through turbines. There is one-shaft 
model that has a generator, compressor and turbine on the same shaft, and two-shaft models which have one turbine that drives the compressor, and the second to drive the generator. As the generator shaft is rotating at high rotation-per-second, high frequency generator produces AC electricity which is rectified to DC and then inverted back to AC with the frequency of $60 \mathrm{HZ}$ for the U.S. market or $50 \mathrm{HZ}$ for European market. Figure 4 shows a scheme of single shaft microturbine CHP system.

\subsection{Steam Turbine Technology}

Unlike the other technologies used in CHP systems, steam turbines are independent from the type of fuel because they do not use the fuel directly [14]. Chemical energy of the fuel is transferred to heat energy in steam boilers in combustion process, after which is used to heat water and turn it to a high temperature steam. Steam is then expanded through the steam turbine where its pressure and temperature drop, while steam energy is transferred to mechanical energy on the steam turbine shaft. After the steam turbine, low pressure and temperature steam go to condenser where the heat is taken away and steam is turned into liquid. From the condenser water goes to pump which raises its pressure to the turbine's inlet pressure. Steam boiler firstly heats the water to the bubbling point, then evaporates it to the steam phase line, and then heats the steam to the steam turbine inlet temperature. These three phases are done in the steam boiler components that are called economizer, evaporator and superheater. Thermodynamic cycle which is used in the steam turbine plants is called Rankine cycle [15].

Even though steam turbine price is competitive with other prime movers, the whole system which includes a steam boiler and other equipment has quite a high price per in-stalled unit of power. This is why steam turbine CHPs are well

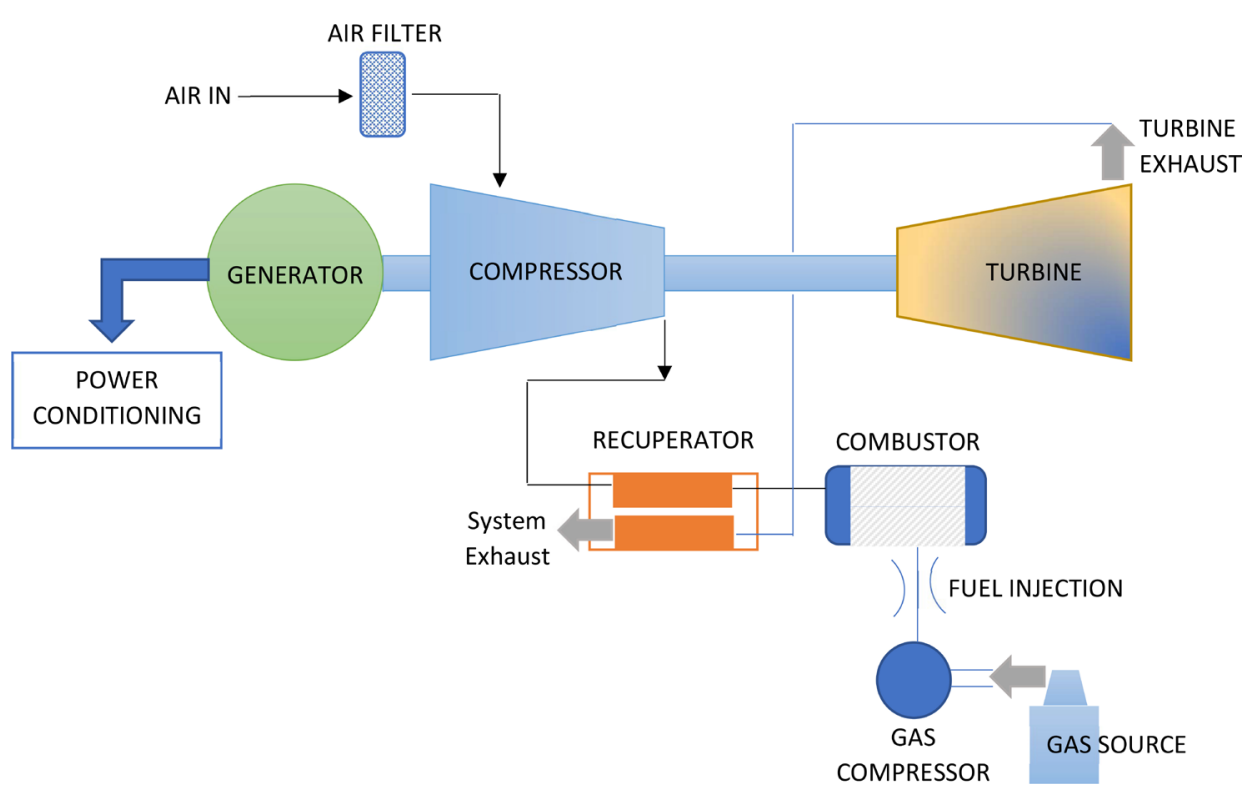

Figure 4. Single Shaft micro turbine CHP system [16]. 
suited for medium and large-scale applications, especially if there are inexpensive fuels available, such as biomass, various solid waste and by-products, refinery oil and gas. In CHP systems, heat can be extracted and used in many different ways. One is using a back-pressure turbine where the expansion is interrupted at some point, other is using an extraction-condensing turbine where one part of the steam is extracted and then used, and there is possibility to produce steam and hot water for the heat directly in the steam boiler. Figure 5 shows systems with the back-pressure turbine and the extraction-condensing turbine.

\subsection{Internal Combustion Engines}

Internal combustion engines are a well-known and widely used technology, especially in the transportation sector. They are as well used for power generation, usually for the standby and emergency power, peaking service, intermediate and baseload, and for combined power and heat generation. There are two types of internal combustion engines: spark ignition (SI) and compression ignition engines (CI). Spark ignition engines used for power generation usually run on natural gas, but they can also use gasoline, propane or the landfill gas. Compression ignition engines, also known as diesel engines, use diesel or heavy oil fuel. They were very popular in power generation, but nowadays they have very limited application because of the emission concerns [17] [18] [19] [20]. Internal combustion engines are very well suited to a variety of distributed generation applications. They have a good partial load efficiency, high reliability, and they start quickly. If we also consider the fact that this technology is relatively low priced and it is very easy for maintaining and operating, there is no wonder why it is used worldwide.

Internal combustion engines operate on Otto and Diesel thermodynamic cycles. The main difference between these two cycles is in ignition, so in Otto cycle engines, there is a device that makes the ignition spark, while in Diesel cycle engines, the fuel ignites when compressed. Mechanically, these two engines
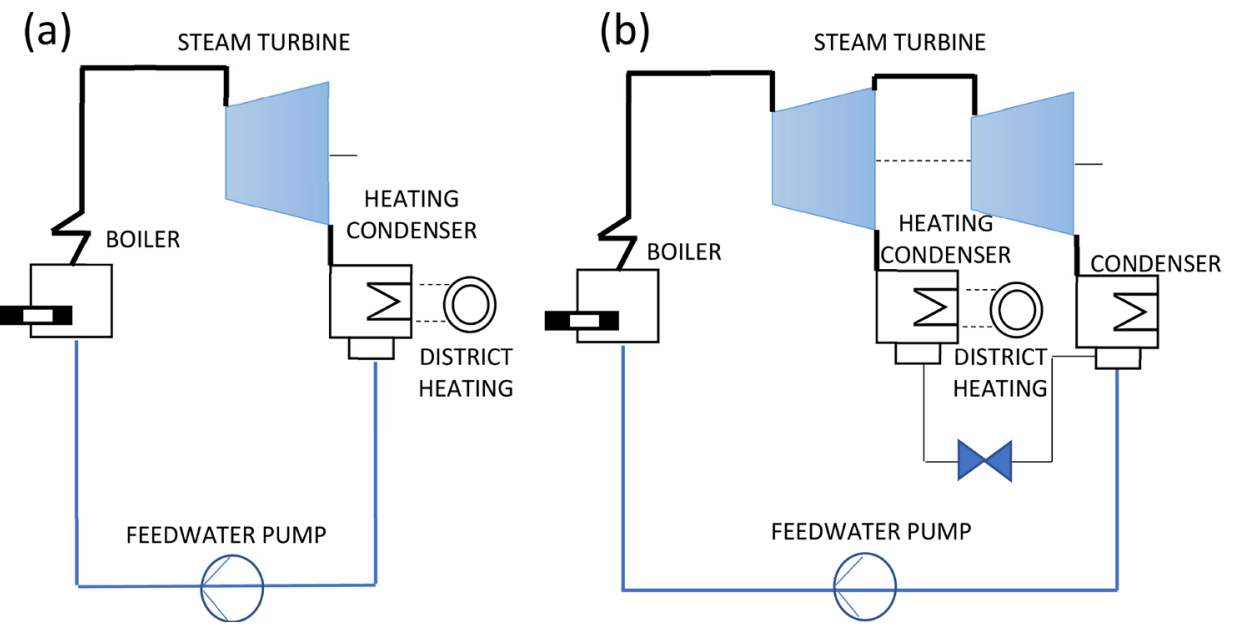

Figure 5. (a) Elements of back-pressure steam turbine cycle, (b) extraction condensing turbine [21]. 
are quite similar: Fuel is ignited and combusted in the cylinder with the piston which is connected to the crankshaft which is transforming linear movement of the piston to rotation.

In CHP applications, the internal combustion engine waste heat can be used from four different sources: exhaust gas, engine jacket cooling water, lube oil cooling water and turbocharger cooling. This heat recovered from internal combustion engines is suitable for the low temperature processes, space heating, portable water heating, or for driving absorption cooling systems. Figure 6 shows how waste heat can be used in the internal combustion engines.

\subsection{Fuel Cells Technology}

Fuel cells technology has a totally different approach to energy production then the other prime movers mentioned above. Like the batteries, fuel cells produce direct current electricity (DC) trough electrochemical processes without the direct combustion of fuel.

Two electrodes, a cathode and anode, pass the charged ions to electrolyte to generate electricity and heat [22] [23] [24] [25]. This technology offers a clean, quiet and efficient power generation. Since there is no combustion, there are no direct emissions associated with this technology. Fast development of this technology started 40 years ago as the fuel of the future and currently, some fuel cell systems are already available for the commercial use. However, these systems face competition problems such as low energy density, expensive materials in use for their production, system complexity and unproven durability and reliability. Because of these problems, it is very hard to ensure funds for their development and production, but as this technology is proven to be environmentally friendly and highly efficient, there are many incentive programs that can help mitigate their cost level.

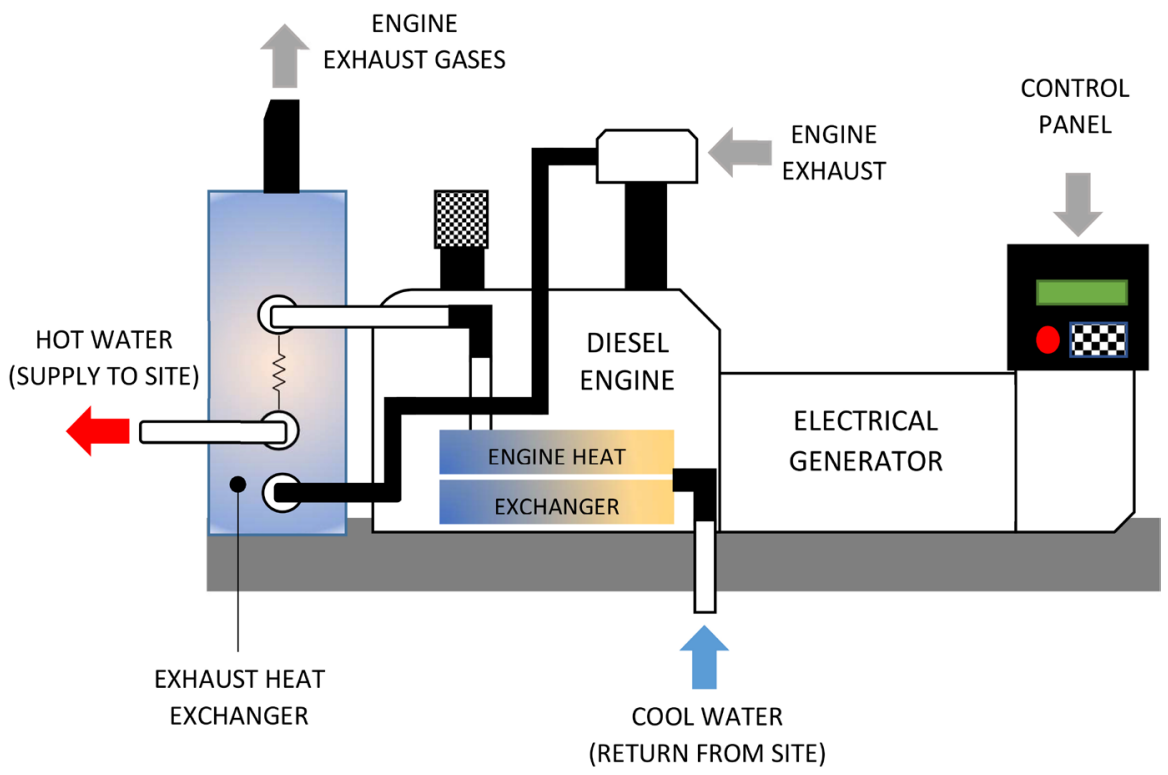

Figure 6. Internal combustion engine in CHP technology [26]. 
Fuel cells use hydrogen as the most common fuel. Hydrogen is usually derived from hydrocarbons such as natural gas and then used in the fuel cells. Most of the fuel cell systems have three main subsystems:

1) The fuel cell that generates direct current electricity;

2) The fuel processor that converts natural gas to hydrogen;

3) The power conditioner that process electrical energy into AC or regulated DC.

As the production cost of the fuel cell technology is high, they are often used in CHP systems in order to achieve higher efficiency [27]. Waste energy is usually used for the district heating applications. Figure 7 shows the scheme of one fuel cell CHP plant.

\section{Biomass and the Benefits Associated with Local Bioenergy Production}

Biomass is considered to be a renewable but limited energy source [28]. It is renewable for the same reason solar energy is: the sunlight is an inexhaustible source of energy. Unlike the wind, solar or hydro energy, biomass needs a long period of time to be generated. Sometimes that time can be measured in years, so usage of biomass requires careful and long-term planning. It is considered to be limited source because it requires land for the plants to grow [29]. Growing world population makes growing demand for the food production, so occupying the land for growing high energy biomass crops can sometimes be opposed to growing food crops. The other difference of biomass from other renewable energy sources is that it cannot be used onsite. Biomass needs to be transformed into heat energy, while the others can be transformed into mechanical or even directly to electrical energy.

According to [30], biomass includes a wide range of products and byproducts from forestry and agriculture as well as municipal and industrial waste streams. It specifically includes:

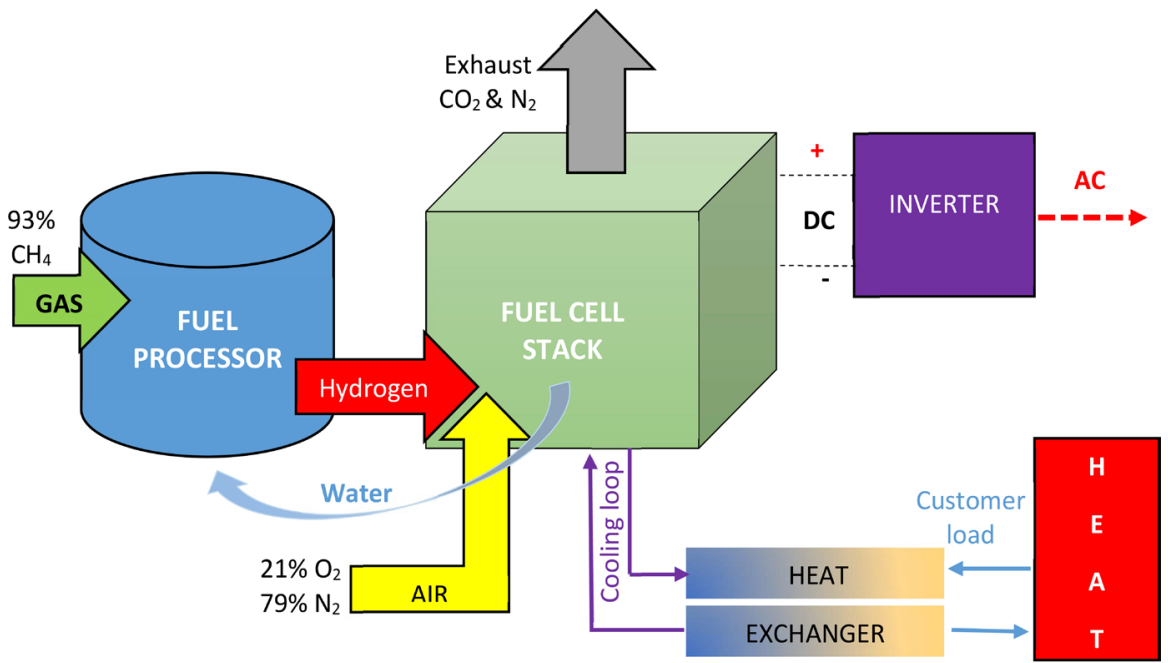

Figure 7. Fuel cell CHP plant [28]. 
Trees; Arable crops; Algae; Agricultural and forest residues; Effluents; Sewage sludge; Manure; Industrial by products; Organic fraction of municipal solid waste.

Biomass can be directly combusted in order to get heat energy, fermented into fuels on alcohol basis, or transformed into high energy gas. The way biomass energy is produced or consumed depends on many different factors among which conversation technologies, specific chemical and physical properties of biomass and energy demands are available [31]. For the heat and electricity production through direct biomass combustion, any biomass feedstock could be effectively used. However, wood-based biomass is traditionally used for these kinds of applications. On the other hand, in transportation appliances, solid biomass needs to be transformed by the refining process to liquid or gas fuel, also known as biofuel.

Figure 8 shows different ways to get energy from biomass [32]. It can also be seen that, conversation, and transport of biomass requires additional process energy which very often origins from fossil fuels. This means that less energy required for the production of energy from biomass means more energy for the final consumers (higher net-energy value) and less greenhouse gases emission. In general, liquid biofuels have low net-energy value, while direct combustion of solid biomass ensures the highest net-energy value. On the other hand, liquid and gas biofuels have other advantages such as easier distribution and consumption, especially in conventional engines used in the transportation sector. Having this in mind, biomass efficiency can be extended from net-energy value to aspects such as available technologies, biomass availability, economic factors as well as culture and lifestyle. Starting point of bioenergy systems is the main elements of biomass production: sunlight, wind, rain, soil and human work. In order to be competitive, bioenergy systems must be effective. Sustainable bioenergy systems can be defined in different ways, therefore different models for sustainability measuring have been developed. According to Börjesson [33], standard model for bioenergy systems is comprised of four aspects: resource,

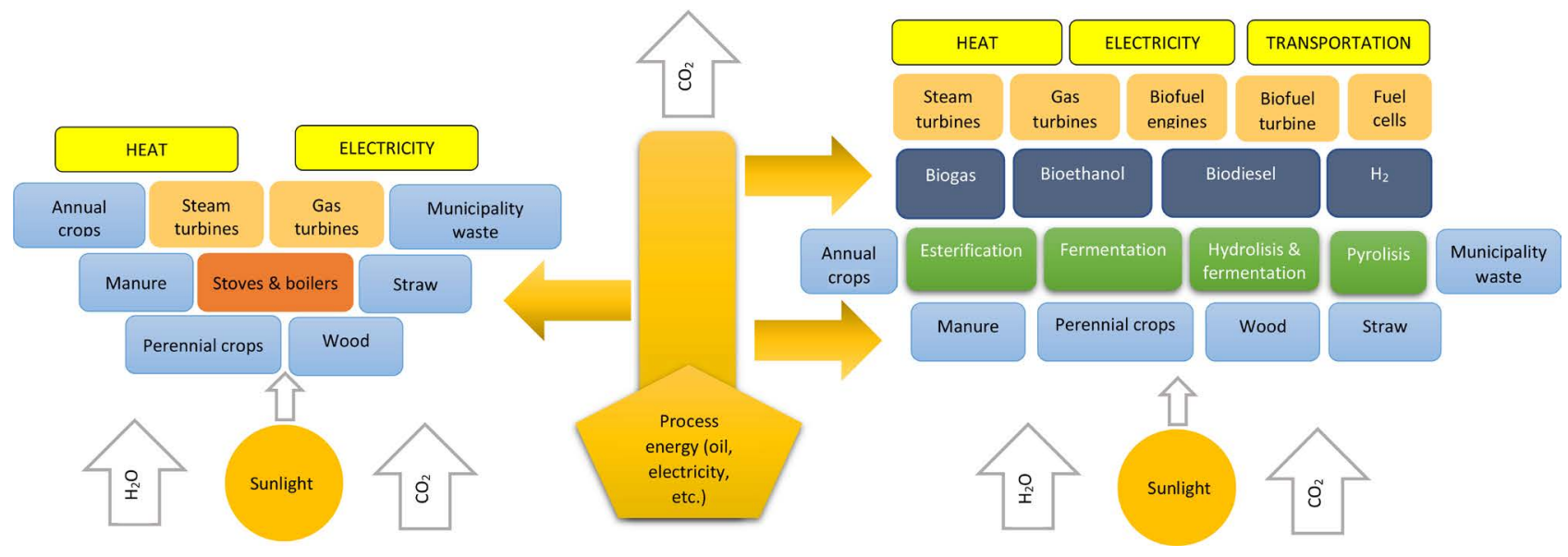

Figure 8. Biomass to energy conversion. 
energy, environmental and cost efficiency.

The model presented by J. Domac, K. Richards and S. Ristovic [34] illustrates the complexity of bioenergy systems by identifying socio-economic benefits associated with local bioenergy production. The model divides the benefits in four dimensions: Social aspect, Macro Level, Supply side and Demand Side. Social aspects are divided into two categories: Increased standard of living and Social cohesion and stability. The first one refers to each household income in economic terms, but since there are some factors that influence living standard which has no immediate economic value such as health, environment and education, those have been added separately.

Introducing bioenergy production could help dealing with social problems that many countries have (high level of unemployment, rural depopulation, etc.). Deploying bioenergy plant would first have influence on direct employment, and then to employment in related industries such as agriculture (see $\mathrm{Ta}$ ble 2).

On macro level, bioenergy contributes to all important elements of development: economic growth through business expansion and employment, substitution for energy import, and secure energy supply trough diversification of energy sources [34]. The supply side effects are more subjective to regional development and they are based on increasing region's competitiveness through bioenergy production. It presumes that the investment in bioenergy system will

Table 2. Benefits associated with local bioenergy production [34].

\begin{tabular}{|c|c|}
\hline Dimension & Benefits \\
\hline Social aspect & $\begin{array}{l}\text { - Increasing standard of living } \\
\text { - Environment } \\
\text { - Health } \\
\text { - Education } \\
\text { - Social cohesion and stability } \\
\text { - Regional development } \\
\text { - Rural diversification }\end{array}$ \\
\hline Macro level & $\begin{array}{l}\text { - Security of supply/risk diversification } \\
\text { - Regional growth } \\
\text { - Reduced regional trade balance } \\
\text { - Export potential }\end{array}$ \\
\hline Supply side & $\begin{array}{l}\text { - Increased productivity } \\
\text { - Enhanced competitiveness } \\
\text { - Labor and population mobility } \\
\text { - Improved infrastructure }\end{array}$ \\
\hline Demand side & $\begin{array}{l}\text { - Employment } \\
\text { - Income and Wealth creation } \\
\text { - Induced Investment } \\
\text { - Support of Related Industries }\end{array}$ \\
\hline
\end{tabular}


bring other investments and develop other industries in the region. The demand side refers to the extent and direction of capital flow to employment and regional income. It can be categorized into direct, indirect, induced and displacement effects [35].

\section{Case Study-Anticosti Island}

Anticosti Island is an island in the province of Quebec, Canada at the outlet of the Saint Lawrence River into the Gulf of Saint Lawrence, between $49^{\circ} \mathrm{N}$ and $50^{\circ} \mathrm{N}$, and between $61^{\circ} 40^{\prime} \mathrm{W}$ and $64^{\circ} 30^{\prime} \mathrm{W}$. At $7892.52 \mathrm{~km}^{2}$ (3047.32 sq.mi) in size and the $20^{\text {th }}$ largest island in Canada. It has about 250 inhabitants and ensures its electrification with the Port-Menier diesel power plant. Figure 9 shows the geographical location of the island.

\subsection{Reference Case (Present Case)}

Local thermal production, using diesel generators, mainly supplies electricity and heating to customers. According to [36], the Port-menier power plant is responsible for high emissions of $\mathrm{CO}_{2}$ annually. For the purpose of design of power plant, peak values of heat and electricity were used. The data from 2016 show that the maximum electricity demand was at $1.2 \mathrm{MW}$. Figure 10 shows the heat and electricity load of the Anticosti community in 2016. This work is focused on the feasibility study of a biomass cogeneration plant to replace the diesel plant with a heat network.

The daily fuel consumption (diesel) is between $7200 \mathrm{l} / \mathrm{d}$ to $8000 \mathrm{l} / \mathrm{d}$ which corresponds in money to $10,368 \mathrm{CAD} \$$ to $11,520 \mathrm{CAD} \$$ per day. The plant has three generators $(2 \times 855 \mathrm{~kW}$ and $1 \times 1135 \mathrm{~kW})$ individually capable of supplying

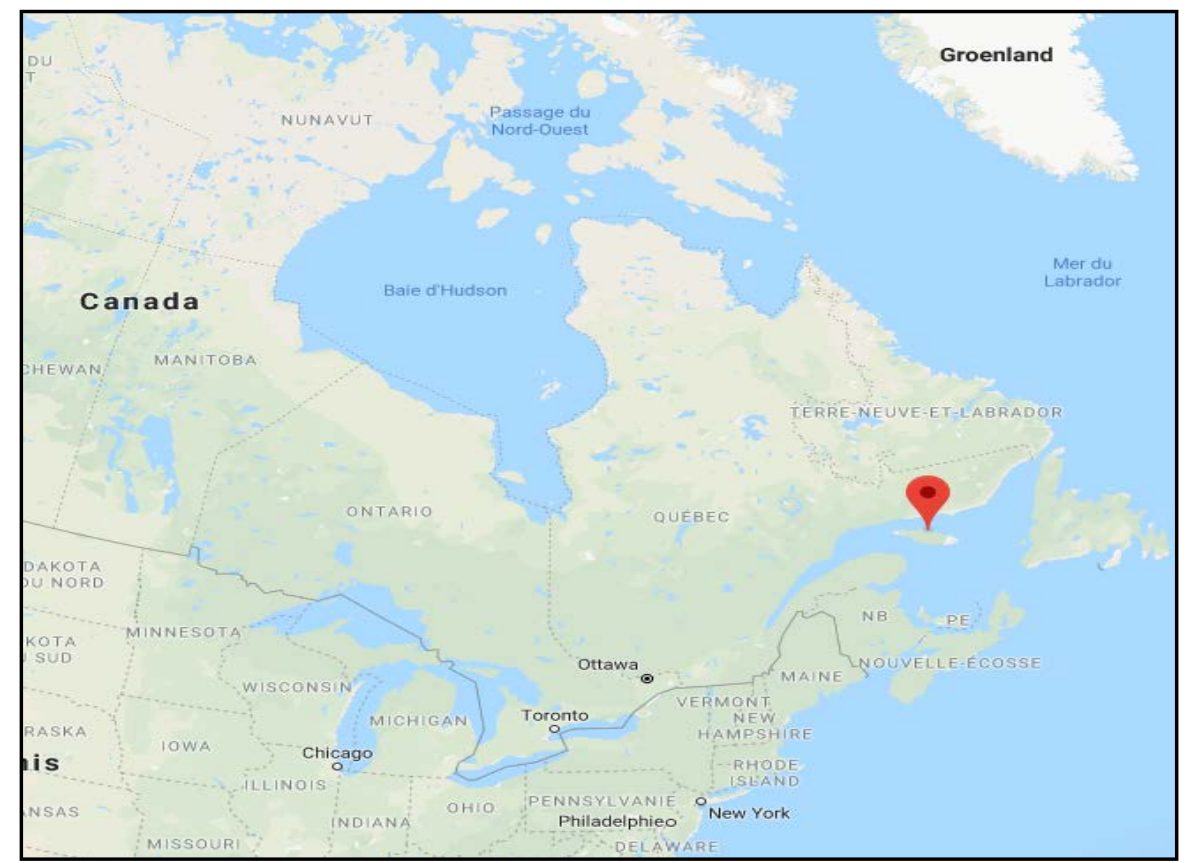

Figure 9. The geographical location of the Anticosti island (Source: google map). 
almost all the electricity required for the proper functioning of the Menier port. The diesel power plant consumes between 1,200,000 and 1,500,000 liters of diesel annually and produces $2845 \mathrm{MW}$. Hydro-Québec forecasts an annual increase in subscriptions of $1.3 \%$ due to the number of inhabitants that increases during the summer season (hunters, tourists, hikers, etc.). The power plant meets the needs of the inhabitants and organizations of the port Menier, a consumption of 4.5 $\mathrm{GWh}$, the rest is released in the form of heat and gas in the air (not used).

\subsection{Proposed Case}

In the proposed case, it is a cogeneration plant operating on biomass (chips and bark), it will produce electricity and heat to supply the heating network with hot water. As shown in Figure 11, the plant operates with Rankine organic cycle units. To meet the electricity demand, the plant must produce $2.2 \mathrm{MW}$ (2 units of 1.1 MW) from biomass combustion, in which case the biomass plant will replace the diesel plant.

\subsection{CHP Design}

The cogeneration plant will be equipped by:

- Two ORC cogeneration turbogenerators with a net capacity of $1.1 \mathrm{MW}$ each.

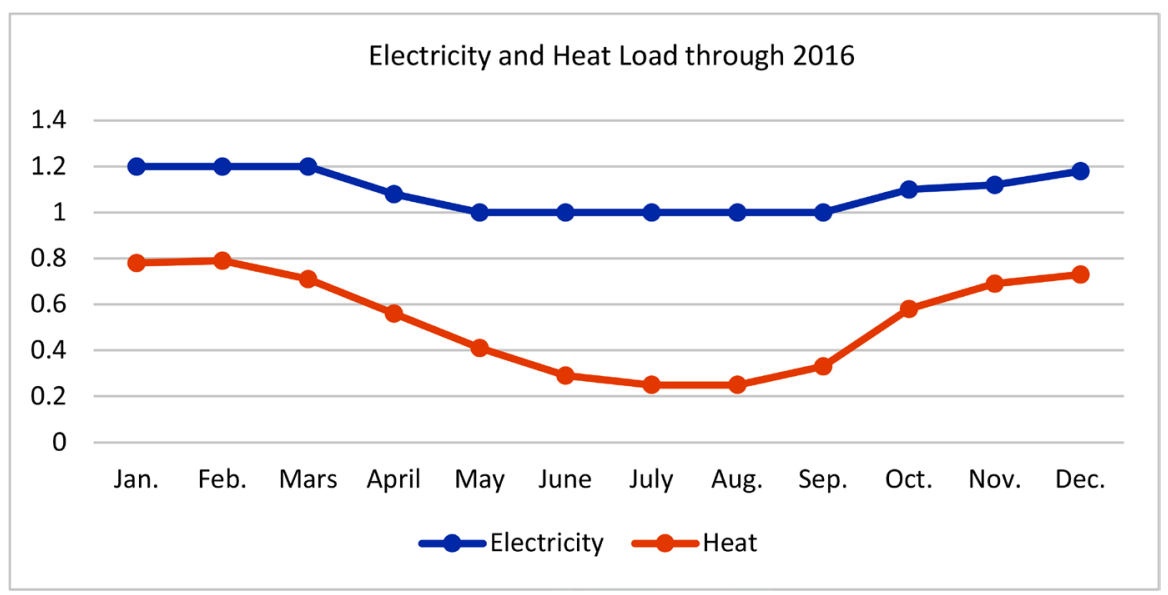

Figure 10. Heat and Electricity peak value demands for the Anticosti Island community in 2016.

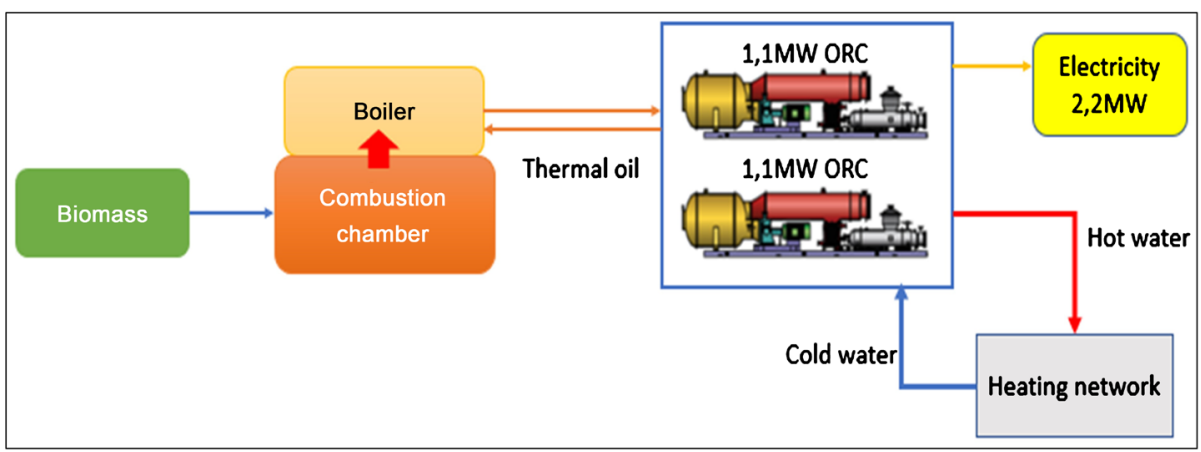

Figure 11. Explanatory diagram of the proposed. 


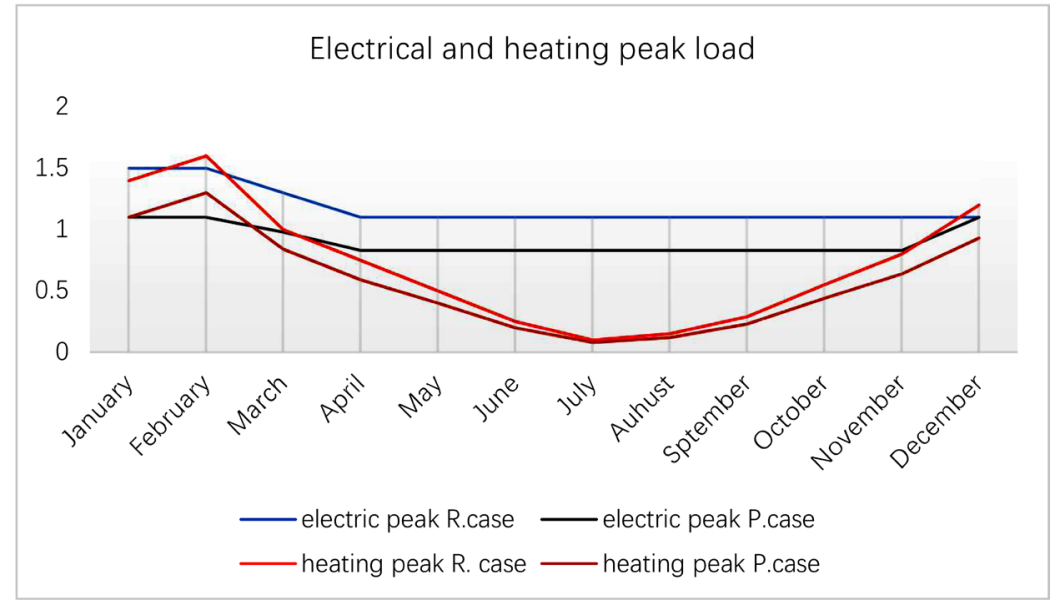

Figure 12. Electrical and heating peak load for the two cases.

They are supplied with thermal oil from the boiler at a power of $5140 \mathrm{kWh}$ to produce electricity and hot water.

- A thermal boiler with a power of about $11 \mathrm{MW}$ and an inlet temperature of $253^{\circ} \mathrm{C}$ and an outlet temperature of $313^{\circ} \mathrm{C}$. The boiler operates on biomass, especially chips and bark, with a moisture content that varies between 25 and $60 \%$. The most appropriate type of boiler is the mobile grate furnace boiler which is able to burn any type of biomass with a moisture content ranging from $10 \%$ to $60 \%$ for a power ranging from $400 \mathrm{~kW}$ to $25 \mathrm{MW}$.

- A biomass conveyor.

- An induced fan, with motorization and variable speed drive designed for high temperature and which conveys the combustion gases leaving the dust collector to the chimney.

- Ash extractor and conveyor to remove ashes to the outside.

- Ash plan.

- Chimney and gas pipes.

- Multi-cyclone type dust collector.

- Main power supply panel and control equipment panel with operator interface.

Energy demand and consumption in the village of Port-Menier is stable over several months of the year and does not exceed 1.1 MW except in December, January and February when the peak loads reach 1.5 MW. With the heating network the electricity demand decreases by $0.4 \mathrm{MW}$ (see Figure 12).

The selected turbogenerators are Turboden TD10 CHP type, they equiped with a turbine, an asynchronous generator, a condenser, an evaporator and a regenerator, they are built by Turboden/pratt \& whitney. The ORC process operates in a closed cycle with thermal oil for a required thermal power of $5250 \mathrm{~kW}$ for each 1.1 MW unit. The thermal output of the ORC unit is $4130 \mathrm{~kW}$ to the condenser, this energy is sent to the district heating network.

The technical data in the following Table 3 are based on an ambient temperature of $15^{\circ} \mathrm{C}$ with a biomass of $40 \%$ moisture at a calorific value of $2.5 \mathrm{kWh} / \mathrm{kg}$. 
The calorific value of biomass is set by RETScreen at $19.8 \mathrm{MJ} / \mathrm{kg}$ for wood and eqaul to $5.4 \mathrm{kWh} / \mathrm{kg}$. Table 4 represents the different characteristics of electricity and biomass consumption.

\subsection{The Heating Network}

Despite its small population and remoteness from major centers, Port-Menier village has all the services necessary for the daily activities of its residents. The number of dwellings occupied by residents is 122 plus 60 detached houses, making a total of 182 residential dwellings. The heating network circuit must be able to meet the needs of the inhabitants for hot domestic water and space heating.

The entire network is divided into four main sections, the first section represents all houses and private dwellings (182), the second section represents the entire Saint-Joseph school and community radio, the third section represents offices,

Table 3. Technical data of a 1.1 MW ORC cogeneration unit.

\begin{tabular}{cc}
\hline Heat transfer fluid & Thermal oil \\
Inlet temperature & $313^{\circ} \mathrm{C}$ \\
Outlet temperature & $253^{\circ} \mathrm{C}$ \\
Working fluid-ORC & Silicone oil \\
Cooling fluid & Water \\
Inlet temperature & $60^{\circ} \mathrm{C}$ \\
Outlet temperature & $80^{\circ} \mathrm{C}$ \\
Input thermal power-ORC & \\
Net electrical power & $5.25 \mathrm{MW}$ \\
Thermal power at the ORC condenser output (to the heating network) & $1.10 \mathrm{MW}$ \\
Net electrical efficiency & $4.13 \mathrm{MW}$ \\
Thermal efficiency & \\
Energy loss & $20 \%$ \\
\hline
\end{tabular}

Table 4. Biofuel power production and consumption characteristics.

\begin{tabular}{ccc}
\hline Parameter & unit & Value \\
\hline Number of cogeneration units & MW & 2 \\
Net electrical power per unit & MWh & 1.1 \\
Total annual electricity production & MWth & 8017.2 \\
Required thermal power & MJ/kg & 10.5 \\
Calorific value of biomass & $\%$ & 19.8 \\
Boiler efficiency & $\mathrm{t} / \mathrm{year}$ & 80 \\
Biomass consumption & $\mathrm{Kg} / \mathrm{h}$ & 19,787 to 39,575 \\
Total consumption /h & $\$$ & 2290 to 4680 \\
Biomass price envisaged & & 55
\end{tabular}


and the fourth section represents the CLSC hospital. According to the 2016 census profile, the number of private dwellings is 182 compared to 218 inhabitants. The heating network will cover the heating needs of the inhabitants with a production capacity of $4130 \mathrm{~kW}$ and a total length of pipes reaching $9750 \mathrm{~m}$. The total investment cost on the heating network is $\$ 14,941,614$. Table 5 covers all expenses during the work, labor, equipment and piping.

The RETScreen renewable energy management software has calculated the model for the heating network (Table 6). The RETScreen database contains the technical data of the piping according to Canadian standards.

The RETScreen model calculates the section and length of the pipes according to Canadian standards and thus calculates the price of the pipes according to standard costs. Table 7 shows the dimensioning and cost of the main line pipes.

The model provides a summary of the dimensions (diameters) of the main distribution line pipes and the related costs.

\section{Economic Analysis}

\subsection{Costs and Investments}

To define the costs of the various equipment of the cogeneration plant, we used

Table 5. Overview of the technical and investment data of the heating network.

\begin{tabular}{ccc}
\hline Parameter & unit & Value \\
\hline Outlet temperature & ${ }^{\circ} \mathrm{C}$ & 80 \\
Return flow temperature & ${ }^{\circ} \mathrm{C}$ & 20 \\
Number of private accommodations & & 182 \\
Number of offices & & 13 \\
Schools and hospitals & & 2 \\
Average distance between buildings & $\mathrm{m}$ & 20 \\
Total length of main line pipes & $\mathrm{m}$ & 6000 \\
Total length of pipes & $\mathrm{m}$ & 9750 \\
Available heat capacity & {$[\mathrm{kW}]$} & 4130 \\
Heat consumed & {$[\mathrm{MWh}]$} & 4735 \\
Total investments cost on the heating network & $\$$ & $14,941,614$ \\
\hline
\end{tabular}

Table 6. Dimensioning and cost of the secondary lingne pipes of the heating network.

\begin{tabular}{cccccc}
\hline Building group & $\begin{array}{c}\text { Length of } \\
\text { the pipes }(\mathrm{m})\end{array}$ & $\begin{array}{c}\text { Size of } \\
\text { the pipes } \\
(\mathrm{m})\end{array}$ & $\begin{array}{c}\text { Cost of the } \\
\text { energy transfer } \\
\text { stations }(\$)\end{array}$ & $\begin{array}{c}\text { Cost of the } \\
\text { secondary line } \\
\text { pipes }(\$)\end{array}$ & $\begin{array}{c}\text { Total } \\
\text { cost }\end{array}$ \\
\hline Private hous & 3000 & DN32 & $1,815,891$ & 617,900 & $6,171,900$ \\
School and the radio office & 50 & DN32 & 31,498 & 63,518 & 95,016 \\
Hospital & 200 & DN40 & 21,317 & 254,072 & 275,389 \\
Offices & 500 & DN32 & 119,729 & 670,950 & 790,679 \\
Total & & & & $7,160,440$ & $9,148,876$ \\
\hline
\end{tabular}


the results of the articles cited in reference [37] [38] [39] [40] which are focused on the technical-economic study of Rankine's organic cycle in order to produce electricity and heat. The results allowed us to make Table 8, we also take the results of the articles as a reference and basics for defining the limits and validating the results.

Table 7. Dimensioning and cost of the main lingne pipes of the heating network.

\begin{tabular}{lll}
\hline $\begin{array}{l}\text { Dimensions (diameters) of the main } \\
\text { distribution line pipes }(\mathrm{mm})\end{array}$ & $\begin{array}{l}\text { Length of the main line } \\
(\mathrm{m})\end{array}$ & $\begin{array}{l}\text { Cost of the main line pipes } \\
(\$)\end{array}$ \\
\hline DN40 & 600 & 381,108 \\
DN50 & 400 & 268,380 \\
DN150 & 5000 & $5,143,250$ \\
Total & & $5,792,738$ \\
\hline
\end{tabular}

Table 8. Estimated cost of equipment and investments of the Anticosti island biomass plant.

\begin{tabular}{ll}
\hline Plant capacity & $2200.00 \mathrm{~kW}$ \\
Net annual electricity production & $8017.2 \mathrm{MWh} /$ year \\
\hline
\end{tabular}

Cost of equipment

Power generation equipment

- 2 ORC Units of $1.1 \mathrm{MW}$

$3,700,000 \$$

- Boiler

$1,716,561 \$$

- Furnace

- Convoyer belt

$352,320 \$$

- Flue gas cleaning system

$1,000,000 \$$

- Storage

$500,000 \$$

- Moisture and fire control system

$150,000 \$$

- Ash extraction system

$200,000 \$$

Feasibility study

$100,000 \$$

Development

$3,500,000 \$$

Engineering

$200,000 \$$

Civil engineering works

Fuel cost

- Biomass price

$55 \$ / \mathrm{t}$

- Annual consumption

$39,575 \mathrm{t}$

- Total cost

$2,176,603 \$$

Total costs of the CHP plant

$13,491,084 \$$

Heating network

- Main mine hoses

$5,792,738 \$$

- Secondary line pipes

- Energy transfer stations

Total heating network costs 


\subsection{Financial Analysis}

The financial analysis is an in-depth examination of investment costs, fuel costs of the proposed case, multiple expenses, total saving and annul revenues. The RET Screen clean energy management software has a spreadsheet called Financial Analysis, which simplifies the project evaluation process. Through the input data of financial parameters (discount rate, debt ratio, etc.), simple return, net present value (NPV). The financial analysis provides decision-makers with the financial parameters useful for their analysis.

Forest fuels are regarded as by-products of traditional forestry where tops and branches are harvested simultaneously with high-quality wood along with lowquality trees. Also, hardwood and thinning are included in the energy supplies. Biomass consisting of these four sources is harvested, gathered, dried to a standardized water content, chipped and transferred to the designated terminal site in the model created for financial assessment for forest fuel manufacturing in Anticosti island.

Variables that determine costs of forestry production, and thus also the production of forest fuels have been divided into three groups: Technology, biology and geography. Technology includes harvesting technology, in-forest transportation, drying (storage), chipping technology, and road transportation technology. Biology variable represents variation of trees that are harvested, their transportation and energy calculation. The last one, geography, includes site specific characteristics such as terrain layout, distance to terminal site, etc.

Forest fuel cost is determined by marginal costs, or the additional costs to traditional forestry. Marginal costs are calculated for each of the production stages (harvesting, collecting, drying, chipping and transportation). Variables (technology, biology and geography) influence the biomass sources processing (residues, low quality trees, hardwood and thinning), and thus influence marginal costs.

Price and availability are the final results that are calculated by this model (Table 9). Price of the forest wood is given in CAD/kWh, and the market price for the Anticosti island is about 0.11 CAD\$.

Positive NPV is indication that the project is economically viable, the net value added of the project is $54,827,799 \$$. The RETScreen model calculated the annual savings over the life of the Anticosti Island biomass which is 6,006,192 \$. The financial analysis of the biomass cogeneration plant project shows that the project is profitable. After about 2 years we manage to recover the investment cost thanks to the income it generates, which reduces the risks since the return is fast, it is very important to minimize the risks. Total savings and annual incomes are $9,516,756 \$$, the annual fee is $4,375,033 \$$ for an investment of $28,432,698 \$$.

\section{GHG Reduction}

The use of the biomass for the production of electricity and thermal energy meets the criteria of environmental protection. Biomass is a renewable and $\mathrm{CO}_{2}$ 
Table 9. Financial analysis of the Anticosti island biomass plant.

\begin{tabular}{|c|c|c|}
\hline Parameter & unit & Value \\
\hline \multicolumn{3}{|l|}{ Financials parameters } \\
\hline - Fuel indexation rate & $\%$ & 3 \\
\hline - Inflation rate & $\%$ & 2 \\
\hline - Discount rate & $\%$ & 9 \\
\hline - Re-investment rate & $\%$ & 9 \\
\hline - Project lifetime & Year & 20 \\
\hline \multicolumn{3}{|l|}{ Finanacing } \\
\hline - Incentives and subsidies & $\$$ & \\
\hline - Debt ratio & $\%$ & 70 \\
\hline - project debt & $\$$ & $19,902,889$ \\
\hline - Equity capital invested & $\$$ & $8,529,809$ \\
\hline - Interest rate on the debt & $\%$ & 7 \\
\hline - Duration of the loan & Year & 15 \\
\hline - Payment of the debt & $\$ /$ Year & $2,185,230$ \\
\hline \multicolumn{3}{|l|}{ Investment costs } \\
\hline - Power generation system & $\$$ & $3,701,760$ \\
\hline - Heat production system & $\$$ & $20,455,704$ \\
\hline - Related and miscellaneous infrastructure & $\$$ & $4,275,234$ \\
\hline Total investment costs & $\$$ & $28,432,698$ \\
\hline \multicolumn{3}{|l|}{ Annual fees and debt payment } \\
\hline - Operation and maintenance & $\$$ & 13,200 \\
\hline - Fuel costs proposed case & $\$$ & $2,173,603$ \\
\hline - Debt payment-15 years & $\$$ & $2,185,230$ \\
\hline Total annual costs & $\$$ & $4,375,033$ \\
\hline \multicolumn{3}{|l|}{ Savings and annual income } \\
\hline - Fuel cost-reference case & $\$$ & $4,891,496$ \\
\hline - Electricity export income & $\$$ & $4,625,260$ \\
\hline - Revenue for GHG reduction & $\$$ & 0 \\
\hline Total savings and annual revenues & $\$$ & $9,516,756$ \\
\hline Cash flow and annual income & $\$$ & $5,141,723$ \\
\hline \multicolumn{3}{|l|}{ Financial viability } \\
\hline Simple return & year & 3.9 \\
\hline Return on equity & year & 1.6 \\
\hline Net Present Value (NPV) & $\$$ & $54,827,799$ \\
\hline Annual savings over the lifetime & $\$ /$ year & $6,006,192$ \\
\hline Benefit-cost ratio & & 7.4 \\
\hline Cost of GHG reduction & $\$ / \mathrm{t} \mathrm{CO}_{2}$ & -307 \\
\hline
\end{tabular}

neutral energy source. Improving electricity generation in Canada's remote sites from biomass or other renewable energy sources is one of the primary government objectives. This project contributes to the achievement of the $\mathrm{CO}_{2}$ emission 
reduction target set out in the Kyoto Protocol.

According to the results of the RETScreen software analysis of the cogeneration plant emission forecasts, it is possible to avoid about 19,541.7 $\mathrm{t} \mathrm{CO}_{2}$ /year, which corresponds to $45,445.8$ barrels of crude oil not consumed per year. The following Table 10 shows the quantity of pollutants $\left(\mathrm{CO}_{2}, \mathrm{CH}_{4}, \mathrm{~N}_{2} \mathrm{O}\right)$ emitted by each system in $\mathrm{kg} / \mathrm{GJ}$. The reference case corresponds to the current diesel system and the proposed case corresponds to the replacement biomass plant.

$\mathrm{CO}_{2}$ emitted by biomass is not considered to be a pollutant because at the time of combustion the biomass erases the $\mathrm{CO}_{2}$ absorbed during its life cycle. This quantity of $\mathrm{CO}_{2} 1427.7 \mathrm{t} \mathrm{CO}_{2}$ /year is not very significant compared to the quantity emitted by diesel which estimated at 20,969.4 t CO 2 year (Figure 13).

A comparison between the two systems is shown in Table 11, we can see the characteristics of each of them, the differences between the quantities of fuel consumed and the quantities of greenhouse gas emissions.

Table 10. Quantity of pollutants emitted by each system.

\begin{tabular}{ccc}
\hline Polluting & Reference case kg/GJ & Proposed case kg/GJ \\
\hline $\mathrm{CO}_{2}$ & 266.3 & 0 \\
$\mathrm{CH}_{4}$ & 0.0132 & 0.0299 \\
$\mathrm{~N}_{2} \mathrm{O}$ & 0.0398 & 0.0037 \\
\hline
\end{tabular}

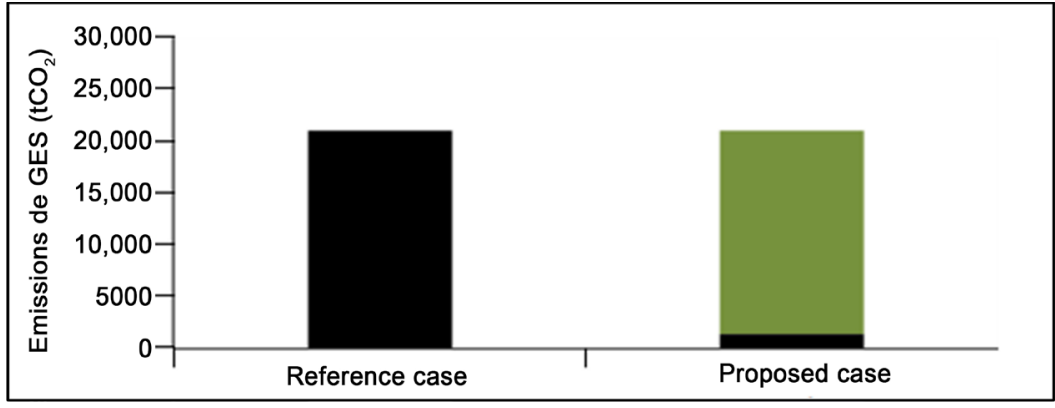

Figure 13. Annual GHG emission reduction graph.

Table 11. Comparing between the two systems (proposed case, reference case).

\begin{tabular}{ccc}
\hline & Proposed case & Reference case \\
\hline Characteristics of the fuel & & \\
Fuel type & biomass & Diesel \\
Calorific Value & $19.8 \mathrm{MJ} / \mathrm{kg}$ & $45.5 \mathrm{MJ} / \mathrm{kg}$ \\
Density mass & 250 to $500 \mathrm{~kg} / \mathrm{m}^{3}$ & $4.845 \mathrm{~kg} / \mathrm{L}$ \\
Purchase price & $55 \$ / \mathrm{t}$ & $1.44 \$ / \mathrm{L}$ \\
Fuel consumption per day & $54.21 \mathrm{t} / \mathrm{d}$ to $108.42 \mathrm{t} / \mathrm{d}$ & 7200 to $8000 \mathrm{~L} / \mathrm{d}$ \\
Fuel consumption per year & 1.2 to $1.5 \mathrm{Ml}$ & $39,575 \mathrm{t}$ \\
Fuel consumption per year & $2.18 \mathrm{M} \$$ & $4.9 \mathrm{M} \$$ \\
Energy production & Power & Heat and power \\
GHG emission & $1427.7 \mathrm{t} \mathrm{CO} / \mathrm{year}$ & $20,969.4 \mathrm{t} \mathrm{CO} / \mathrm{year}$ \\
\hline
\end{tabular}




\section{Conclusion and Perspective Work}

The results of the software show the technical and economic viability of the project, this one is profitable after 2 years with an investment of $28,285,784 \$$ and total annual saving and income of 9,516,756\$. According to the financial analysis, the viability of the project is positive, the return on the initial investment cost of the project thanks to the income it generates is very fast, it represents 1.6 years, which reduce the risks on the investment. In this work, it has been demonstrated the advantage of transforming biomass into energy using ORC cogeneration units. With a capacity of $2.2 \mathrm{MW}$ the system includes two cogeneration units of 1.1 MW each, the demand for electrical energy is 1.1 MW to 1.5 MW throughout the year. The proposed system largely covers the power and heating demand of the Port-Menier Village. This project will create several permanent and semi-permanent jobs, encourage the entrepreneurs to invest in the creation of companies in the field of wood processing, which will boost the island's economy. This system will reduce by 19,543 t CO 2 per year and 390,867 t $\mathrm{CO}_{2}$ over 20 years life of the project.

\section{Conflicts of Interest}

The authors declare no conflicts of interest regarding the publication of this paper.

\section{References}

[1] Abbas, T., Issa, M. and Ilinca, A. (2020) Biomass Cogeneration Technologies: A Review. Journal of Sustainable Bioenergy Systems, 10, 1-15. https://doi.org/10.4236/jsbs.2020.101001

[2] Statistic Norway. http://www.ssb.no/en

[3] U.S. Environmental Protection Agency, Combined Heat and Power Partnership (2008) Catalog of CHP Technologies.

[4] Urošević, B.G. (2009) Combined Heat and Power Production in Industry. Manual for Energy Efficiency Improvements and Energy Conservation in Industry. Innovation Center of Mechanical Engineering Faculty Belgrade, Belgrade.

[5] Rosillo-Calle, F., et al. (2007) The Biomass Assessment Handbook: Bioenergy for a Sustainable Environment. Earthscan, London.

[6] Börjesson, M. and Ahlgren, E.O. (2012) 5.07 Biomass CHP Energy Systems: A Critical Assessment. In: Sayigh, A., Ed., Comprehensive Renewable Energy, Elsevier, Oxford, 87-97. https://doi.org/10.1016/B978-0-08-087872-0.00508-4

[7] Pglaro, R. (2008) Bioenergy and Regional Development in the Nordic Countries.

[8] Domac, J., Richards, K., et al. (2005) Socio-Economic Drivers in Implementing Bioenergy Projects. Biomass \& Bioenergy, 28, 97-106. https://doi.org/10.1016/j.biombioe.2004.08.002

[9] Jungingera, H.M., Jonker, J.G.G., Faaij, A., Cocchi, M., Hektor, B., Hess, R., Heinimö, J., Hennig, C., Kranzl, L., Marchal, D., Matzenberger, J., Nikolaisen, L., Pelkmans, L., Rosillo-Calle, F., Schouwenberg, P., Trømborg, E. and Walter, A. (2011) Summary, Synthesis and Conclusions from IEA Bio-Energy Task 40 Country Reports on International Bioenergy Trade. 
[10] Agency, E.E. (2006) How Much Bioenergy Can Europe Produce without Harming the Environment?

[11] Scarlat, N., Dallemand, J.-F., Skjelhaugen, O.J., Asplund, D. and Nesheim, L. (2011) An Overview of the Biomass Resource Potential of Norway for Bioenergy Use. Renewable and Sustainable Energy Reviews, 15, 3388-3398. https://doi.org/10.1016/j.rser.2011.04.028

[12] Framstad, E., et al. (2009) Increased Biomass Harvesting for Bioenergy-Effects on Biodiversity, Landscape Amenities and Cultural Heritage Values. Tema Nord, Copenhagen.

[13] Vallios, I., Tsoutsos, T. and Papadakis, G. (2009) Design of Biomass District Heating Systems. Biomass and Bioenergy, 33, 659-678. https://doi.org/10.1016/j.biombioe.2008.10.009

[14] Sha, S. and Hurme, M. (2012) Emergy Evaluation of Combined Heat and Power Plant Processes. Applied Thermal Engineering, 43, 67-74. https://doi.org/10.1016/j.applthermaleng.2011.11.063

[15] Bjørnstad, E. (2005) An Engineering Economics Approach to the Estimation of Forest Fuel Supply in North-Trøndelag County, Norway. Journal of Forest Economics, 10, 161-188. https://doi.org/10.1016/j.jfe.2004.11.002

[16] Energy and Environmental Analysis (an ICF International Company) (2008) 1655 North Fort Myer Drive Suite 600 Arlington V. Technology Characterization: Steam Turbines.

[17] Drescher, U. and Bruggemann, D. (2007) Fluid Selection for the Organic Rankine Cycle (ORC) in Biomass Power and Heat Plants. Applied Thermal Engineering, 27, 223-228. https://doi.org/10.1016/j.applthermaleng.2006.04.024

[18] Obernberger, I., Thonhofer, P. and Reisenhofer, E. (2002) Description and Evaluation of the New $1000 \mathrm{kWel}$ Organic Rankine Cycle Process Integrated in the Biomass CHP Plant in Lienz, Austria. Euroheat \& Power, 10, 1-9.

[19] Liu, B., Riviere, P., Coquelet, Ch., Gicquel, R. and Dawid, F. (2012) Investigation of a Two Stage Rankine Cycle for Electric Power Plants. Applied Energy, 100, 285-294. https://doi.org/10.1016/j.apenergy.2012.05.044

[20] DiGenova, K.J., Botros, B.B. and Brisson, J.G. (2013) Method for Customizing an Organic Rankine Cycle to a Complex Heat Source for Efficient Energy Conversion, Demonstrated on a Fischer Tropsch Plant. Applied Energy, 102, 746-754.

https://doi.org/10.1016/j.apenergy.2012.08.029

[21] Trømborg, E., Bolkesjø, T.F. and Solberg, B. (2008) Biomass Market and Trade in Norway: Status and Future Prospects. Biomass and Bioenergy, 32, 660-671. https://doi.org/10.1016/j.biombioe.2008.02.022

[22] Kaminski, J. (2012) The Development of Market Power in the Polish Power Generation Sector: A 10-Year Perspective. Energy Policy, 42, 136-147. https://doi.org/10.1016/j.enpol.2011.11.057

[23] del Río, P., Ragwitz, M., Steinhilber, S., Resch, G., Busch, S., Klessmann, C., et al. (2012) Key-Policy Approaches for a Harmonisation of RES(-E) Support in Europe Main Options and Design Elements. A Report Compiled within the European Research Project beyond 2020 (Work Package 2). Supported by Intelligent Energy e-Europe, Altener (Grant Agreement No. IEE/10/437/SI2.589880). http://www.respolicy-beyond2020.eu

[24] Ragwitz, M. and Resch, G. (2007) Promotion of Renewable Energy Sources: Effects on Innovation. International Journal of Public Policy, 2, 32-56.

https://doi.org/10.1504/IJPP.2007.012275 
[25] del Río, P. and Bleda, M. (2012) Comparing the Innovation Effects of Support Schemes for Renewable Electricity Technologies: A Function of Innovation Approach. Energy Policy, 50, 272-282. https://doi.org/10.1016/j.enpol.2012.07.014

[26] Solinski, B. (2008) Support Mechanisms for the Promotion of Renewable Energy Sources e Feed in Tariff and Tradable Green Certificates Comparison. Energy Policy, 11, 107-119. (In Polish)

[27] Batlle, C., Perez-Arriaga, I.J. and Zambrano-Barragan, P. (2012) Regulatory Design for RES-E Support Mechanisms: Learning Curves, Market Structure, and Burden Sharing. Energy Policy, 41, 212-220. https://doi.org/10.1016/j.enpol.2011.10.039

[28] Butler, L. and Neuhoff, K. (2008) Comparison of Feed-In Tariff, Quota and Auction Mechanisms to Support Wind Power Development. Renew Energy, 33, 1854-1867. https://doi.org/10.1016/j.renene.2007.10.008

[29] The German Renewable Energy Act. BT-Drucks. 17/6071, BT-Drucks. 17/6363. http://www.bmu.de

[30] Polish Power Exchange PolPX. http://www.tge.pl/en

[31] The Polish Energy Law. http://www.ure.gov.pl

[32] Tańczuk, M. and Ulbrich, R. (2013) Implementation of a Biomass-Fired Co-Generation Plant Supplied with an ORC (Organic Rankine Cycle) as a Heat Source for Small Scale Heat Distribution System-A Comparative Analysis under Polish and German Conditions. Energy, 62, 132-141. https://doi.org/10.1016/j.energy.2013.09.044

[33] Strzalka, R., Eicker, U. and Ulbrich, R. (2008) Operational Experiences and Optimization of an ORC Biomass Cogeneration Plant. Proceedings of 16 th European Biomass Conference, Valencia, June 2008, 1-5.

[34] Strzalka, R., Ulbrich, R. and Eicker, U. (2009) Analysis of a Biomass Tri-Generation System in an Urban Area. Proceedings of the 17 th Biomass Conference, Hamburg, 29 June-2 July 2009, 2167-2171.

[35] Erhart, T., Eicker, U. and Infield, D. (2011) Part-Load Characteristics of Organic-Rankine-Cycles. Proceedings of 2 nd European Conference on Poly-Generation, Tarragona, 30 March-1 April 2011, 1-11.

[36] HydroQuebec. http://www.regie-energie.qc.ca/audiences/3648-07/Requete3648/B-1-HQD-02-01_3 648_01nov07.pdf

[37] Quoilin, S., Van Den Broek, M., Declaye, S., et al. (2013) Techno-Economic Survey of Organic Rankine Cycle (ORC) Systems. Renewable and Sustainable Energy Reviews, 22, 168-186. https://doi.org/10.1016/j.rser.2013.01.028

[38] Uris, M., Linares, J.I. and Arenas, E. (2014) Evaluation de faisabilité tech-nicoéconomique d'une centrale de cogénération à la biomasse basée sur un cycle organique de Rankine. Énergies Renouvelables, 66, 707-713. https://doi.org/10.1016/j.renene.2014.01.022

[39] Obernberger, I., Thonhofer, P. and Reisenhofer, E. (2002) Description and Evaluation of the New $1000 \mathrm{kWel}$ Organic Rankine Cycle Process Integrated in the Biomass CHP Plant in Lienz, Austria. Euroheat \& Power, 10, 18-25.

[40] Obernberger, I. and Thek, G. (2004) Techno-Economic Evaluation of Selected Decentralised CHP Applications Based on Biomass Combustion in IEA Partner Countries. 